\title{
ANALISIS BESARAN KOEFISIEN KETIDAKPASTIAN ENVIRONMENTAL UNCERTAINTY (EU) YANG BERPENGARUH PADA PERHITUNGAN BUFFER PADA CRITICAL CHAIN PROJECT MANAGEMENT (CCPM) DI JAKARTA
}

\author{
Ignatius Edward Lianto ${ }^{1}$ dan Basuki Anondho ${ }^{2}$ \\ ${ }^{1}$ Program Studi Sarjana Teknik Sipil, Universitas Tarumanagara, Jl. Letjen S. Parman No.1 Jakarta \\ Email: edwardlianto@gmail.com \\ ${ }^{2}$ Program Studi Sarjana Teknik Sipil, Universitas Tarumanagara, Jl. Letjen S. Parman No.1 Jakarta \\ Email: basukia@ft.untar.ac.id
}

\begin{abstract}
ABSTRAK
Proyek konstruksi rentan terhadap berbagai macam kendala, seperti kompleksitas proyek, kelangkaan sumber daya, dan ketidakpastian durasi proyek. Terdapat sebuah metode untuk penjadwalan konstruksi yang bernama Critical Chain Project Management (CCPM). Terdapat dua tantangan dalam implementasi CCPM pada penjadwalan konstruksi, salah satunya adalah pengukuran buffer. Buffer memiliki peran penting untuk memastikan keberhasilan manajemen jadwal. Metode UncertaintyAware Method (UAM) digunakan untuk menghasilkan buffer yang proporsional dengan memperhitungkan beragam ketidakpastian. Salah satu jenis ketidakpastian pada UAM adalah Environmental Uncertainty (EU). Penelitian ini bertujuan mengetahui koefisien Environmental Uncertainty dengan penyebaran kuesioner pada proyek di Jakarta. Metode Relative Importance Index (RII) digunakan untuk menganalisis data. Berdasarkan koefisien yang diperoleh dari hasil perhitungan, proyek di Jakarta mempunyai ketidakpastian Environmental Uncertainty yang besar.
\end{abstract}

Kata kunci: critical chain project management, manajemen konstruksi, ketidakpastian, perhitungan buffer, environmental uncertainty.

\section{PENDAHULUAN}

\section{Latar Belakang}

Proyek konstruksi sangat rentan terhadap berbagai macam kendala, seperti kompleksitas proyek, kelangkaan sumber daya, dan ketidakpastian durasi proyek. Kegagalan untuk mengatur salah satu dari kendala ini akan mengakibatkan gangguan pada proyek yang berujung pada bertambahnya durasi proyek (Ma et al., 2014). Ma et al. (2014) mengembangkan Critical Chain Project Management (CCPM) yang didasari oleh usulan dari Goldratt (1997) yaitu Theory of Constraints (TOC). Metode penjadwalan proyek mulai menujukkan perkembangan dengan adanya TOC. TOC digunakan untuk mengatur produksi yang repetitif yang didasari dengan paham bahwa setiap sistem memiliki batasan, dan performa sistem hanya dapat dikembangkan dengan meningkatkan performa resource yang terbatas tersebut. Untuk menghindari keterlambatan proyek, CCPM mengembangkan sistem penjadwalan menggunakan buffer (Cohen et al., 2004). Karena banyaknya ketidakpastian yang sering terjadi pada proyek konstruksi, buffer memegang peranan penting dalam CCPM (Raz et al., 2003) sehingga ketahanan proyek terhadap ketidakpastian meningkat dan durasi proyek terjaga.

Terdapat dua metode yang digunakan untuk mengukur besarnya buffer: the cut and paste method (C\&PM) dan the root square error method (RSEM). C\&PM mengadopsi sebuah prosedur yang linear. Semakin panjang critical chain, semakin besar buffer yang dihasilkan sehingga seringkali menghasilkan jadwal yang panjang dan mengakibatkan terbuangnya resources (Herroelen dan Leus, 2001). RSEM tidak menghasilkan jadwal yang panjang seperti C\&PM (Tukel et al., 2006), tetapi dapat menghasilkan jadwal yang rentan terhadap beragam ketidakpastian. Selain kedua metode diatas, Ma et al. (2014) mengembangkan metode perhitungan buffer yang disebut UncertaintyAware Method (UAM) untuk menentukan ukuran buffer yang masuk akal dengan memperhitungkan beragam faktor yang mempengaruhi penjadwalan proyek dan belum diperhitungkan dalam metode sebelumnya. Beragam faktor tersebut adalah Environmental Uncertainty, Activity Complexity, Activity Flexibility, Resource Tightness, dan Risk Preference. 


\section{Tujuan Penelitian}

Berdasarkan latar belakang, tujuan dari penelitian ini adalah memperoleh besaran koefisien ketidakpastian Environmental Uncertainty (EU) untuk perhitungan buffer pada proyek konstruksi di Jakarta.

\section{Critical Chain Project Management (CCPM)}

Dalam novelnya yang bernama Critical Chain, Goldratt (1997) mengemukakan sebuah teori yang bernama TOC (Theory of Constraints). TOC adalah alat untuk mengatur sistem produksi yang berulang yang didasari oleh prinsip yang mengatakan bahwa setiap sistem memiliki kendala (constraint) dan kinerja sistem hanya dapat ditingkatkan dengan cara meningkatkan kinerja dari resource yang mengalami kendala. CCPM adalah perpanjangan dari TOC yang didesain hanya untuk lingkungan proyek (Raz et al., 2003). CCPM menggunakan penjadwalan deterministic yang terintegrasi dengan mekanisme buffer untuk mengatasi resource constraints dan ketidakpastian (Long dan Ohsato, 2008). CCPM menghilangkan hidden safety pada durasi aktivitas untuk melindungi dari keterlambatan dalam dimulainya aktivitas (Student Syndrome) dan usaha untuk menyibukkan diri di sepanjang durasi aktivitas (Parkinson's Law). Safety time ini kemudian dikumpulkan dan diletakkan di beberapa posisi penting sebagai buffer untuk menyerap keterlambatan. Selain itu, CCPM digunakan untuk melindungi anggota tim proyek dari gangguan dan multi-tasking, mengalihkan pengukuran tugas dari on time task completion menjadi on time project completion (Rabbani et al., 2007). Segala aktivitas sebisa mungkin dijadwalkan terlambat (as late as possible) agar biaya tidak dikeluarkan lebih cepat dari yang diperlukan.

Menurut Ma et al. (2014), terdapat dua tantangan utama dalam pelaksanaan CCPM, yaitu buffer sizing dan multiple resources leveling. Metode CCPM tidak menempatkan safety time pada setiap aktivitas secara individual. Sebaliknya, CCPM menempatkan sebuah aggregated safety time dan meletakknya di beberapa posisi pada critical chain untuk berfungsi sebagai buffer. Buffer memperhitungkan precedence constraints dan resource constraints, dan berperan dalam memperpendek durasi proyek serta meningkatkan ketahanan (robustness) dari penjadwalan proyek. Buffer memainkan peran kunci dalam CCPM (Raz et al., 2003) dan pengukuran buffer sangat penting untuk meningkatkan efektifitas dan memastikan kesuksesan manajemen jadwal sebuah proyek. Dua metode yang banyak digunakan dalam perhitungan buffer adalah Cut and Paste Method (C\&PM) dan Root Square Error Method (RSEM). Akan tetapi, C\&PM mengadopsi prosedur linear dan ukuran dari buffer yang dihasilkan semakin besar dengan semakin panjangnya critical chain sehingga mengakibatkan resources yang terbuang (Herroelen dan Leus, 2001). RSEM lebih sedikit terpengaruh oleh panjangnya critical chain, namun RSEM dapat menghasilkan jadwal yang tidak cukup tahan dalam menghadapi berbagai ketidakpastian (Tukel et al., 2006).

Untuk menangani dua tantangan ini dan meningkatkan penerapan dari metode CCPM pada manajemen proyek konstruksi, Ma et al. (2014) mengajukan sebuah framework CCPM yang telah dikembangkan. Framework ini memperkenalkan Uncertainty-Aware Method (UAM) untuk menentukan ukuran buffer yang masuk akal dengan memperhitungkan beragam faktor yang mempengaruhi penjadwalan konstruksi dan belum ikut diperhitungkan pada metode yang ada. Selain itu, framework ini juga mengintegrasikan sebuah Multimode-based Method (MBM) untuk mengatasi masalah multiple resources leveling pada penjadwalan konstruksi berbasis CCPM.

\section{Buffer}

Untuk melindungi critical chain dan dapat melaksanakan proyek sesuai yang direncanakan, Goldratt memperkenalkan konsep dari buffer. Seperti yang disebutkan pada literatur (Patrick, 1999) kegunaan buffer dalam penjadwalan proyek berbeda dengan manajemen slack. Slack times terjadi secara acak pada rencana proyek sehingga pada umumnya mengakibatkan ketidakefektifan dalam membatasi dampak dari beragam durasi aktivitas, dan sebagai hasilnya, durasi proyek. Di sisi lain, buffer dihitung untuk menggambarkan ketidakpastian dalam estimasi durasi aktivitas. Karena banyaknya ketidakpastian yang sering terjadi pada proyek konstruksi, Buffer memegang peranan penting dalam CCPM (Raz et al., 2003) sehingga ketahanan proyek terhadap ketidakpastian meningkat dan durasi proyek terjaga. Menurut Tukel et al. (2006), buffer diartikan sebagai kumpulan waktu yang diambil dari kegiatan pada proyek sehingga kumpulan waktu tersebut dapat digunakan untuk melindungi jadwal proyek dari keterlambatan akibat ketidakpastian.

Terdapat tiga tipe buffer yang dibedakan melalui posisi dan fungsinya, yaitu Feeding Buffer (FB), Project Buffer (PB), dan Resource Buffer (RB).

1. Feeding Buffer (FB)

FB diletakkan pada semua jalur yang akan masuk (feed) ke critical chain untuk mencegah keterlambatan jalur tersebut dalam mempengaruhi waktu dimulainya aktivitas pada critical chain (on-time start of critical tasks) 
(Tukel et al., 2006). FB ditetapkan untuk melindungi critical chain dari beragam kegiatan yang tidak terdapat pada critical chain dan dijadwalkan saat noncritical dan critical activity bertemu (Bevilacqua et al., 2009).

2. Project Buffer (PB)

PB diletakkan pada bagian akhir dari critical chain untuk melindungi durasi proyek sehingga durasi proyek tidak melebihi waktu yang direncanakan (Bie, et al., 2012).

3. Resource Buffer (RB)

RB diletakkan untuk melindungi critical chain dari kelangkaan critical resources melalui peringatan dan tidak memakan waktu (Rand 2000). Sumber daya yang dibutuhkan oleh pekerjaan pada critical chain diartikan sebagai critical resource (Raz et al., 2003). RB digunakan sebagai sinyal dan tidak memerlukan waktu (Raz et al., 2003). Peringatan ini akan menyebabkan critical resource meninggalkan perkejaan noncritical dan siap untuk digunakan pada critical chain segera setelah predecessors nya selesai dikerjakan. RB juga tidak menggunakan resource dan tidak menambah waktu maupun biaya pada proyek (Leach, 2005; Tukel et al., 2006).

\section{Identifikasi Critical Chain}

Menurut Long dan Ohsato (2008), sebuah chain adalah urutan aktivitas yang memperhitungkan precedence dan ketergantungan resource. Ia juga menambahkan bahwa critical chain adalah rantai terpanjang dan menentukan durasi proyek. Bila terdapat banyak critical chain, yang dipilih adalah critical chain dengan ketidakpastian terbesar. Menurut Rand (2000), 'Critical Chain' dari Goldratt diciptakan dalam hubungannya dengan resource allocation. Pada banyak proyek, permasalahan mengenai penggunaan limited resources yang dibutuhkan untuk beberapa aktivitas sering dijumpai. Critical chain didefinisikan sebagai rantai terpanjang dari ketergantungan resource. Untuk menentukan critical chain, perlu adanya pertimbangan mengenai adanya masalah ketergantungan terhadap resource yang dibutuhkan secara bersamaan antar aktivitas. Apabila masalah itu terjadi, aktivitas itu harus dilaksanakan secara berurutan dan tidak secara paralel atau bersamaan. Hal yang membedakan critical chain dengan critical path adalah pada critical path tidak diperhitungkan ketersediaan resource. Ketika terdapat dua critical chain yang memiliki panjang yang sama, dapat dipilih salah satunya (arbitrary) (Tukel et al., 2006).

\section{Perhitungan Buffer dengan Ketidakpastian}

Root Square Error Method (RSEM) mengkalkulasikan Project Buffer (PB) dan Feeding Buffer (FB) seperti berikut (Herroelen dan Leus, 2001):

$$
\begin{aligned}
& \mathrm{PB}=\left(\sum_{i \in\{\mathrm{CC}\}}^{n} \sigma_{i}^{2}\right)^{1 / 2} \\
& \mathrm{FB}_{i}=\left(\sum_{j \in\left\{\mathrm{NC}_{i}\right\}}^{n} \sigma_{j}^{2}\right)^{1 / 2}
\end{aligned}
$$

Keterangan :

$$
\begin{array}{ll}
\sigma_{i} & =\text { Safety Time dari aktivitas } i \\
\sigma_{j} & =\text { Safety Time dari aktivitas } j \\
\mathrm{CC} & =\text { Kumpulan aktivitas pada critical chain } \\
\mathrm{NC}_{i} & =\text { Kumpulan aktivitas pada noncritical chain yang terdapat aktivitas } i \\
n & =\text { Jumlah aktivitas yang harus dilaksanakan tanpa gangguan }
\end{array}
$$

Ma et al. (2014) menciptakan Uncertainty-Aware Method (UAM) dengan Root Square Error Method (RSEM) sebagai dasarnya. Perbedaan mendasarnya adalah diperhitungkannya pengaruh dari beragam ketidakpastian yang tidak terdapat pada RSEM. Perhitungan buffer dikalkulasikan sebagai berikut:

$$
\begin{gathered}
\mathrm{PB}=\mathrm{EU} \times \mathrm{RP} \times \mathrm{AC}_{\mathrm{CC}} \times\left\{\sum_{i \in\{\mathrm{CC}\}}^{n}\left[\left(1+\mathrm{RT}_{i}\right) \times \mathrm{AF}_{i} \times \sigma_{i}\right]^{2}\right\}^{1 / 2} \\
\mathrm{FB}_{i}=\mathrm{EU} \times \mathrm{RP} \times \mathrm{AC}_{\mathrm{NC}_{i}} \times\left\{\sum_{i \in\left\{\mathrm{NC}_{i}\right\}}^{n}\left[\left(1+\mathrm{RT}_{i}\right) \times \mathrm{AF}_{i} \times \sigma_{i}\right]^{2}\right\}^{1 / 2}
\end{gathered}
$$




\section{Keterangan :}

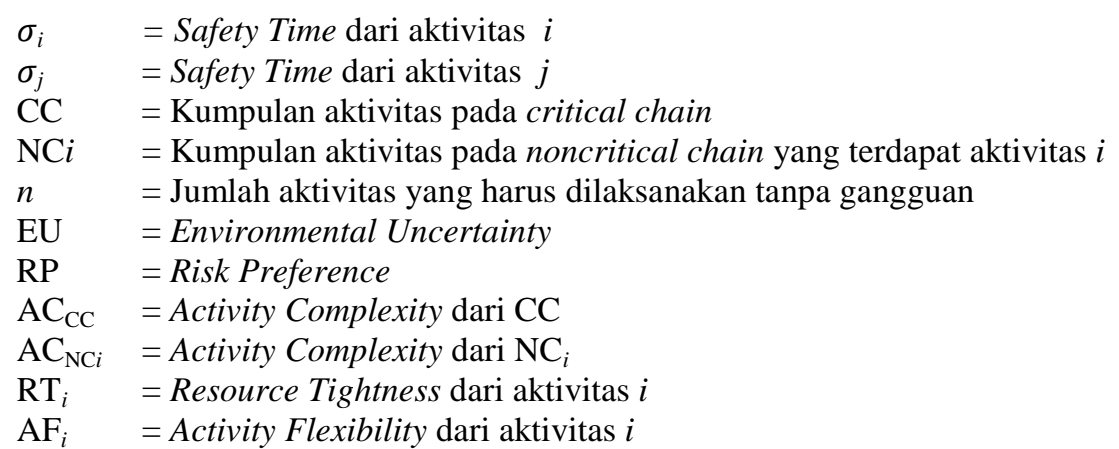

Persamaan (3) dan (4) memperhitungkan efek dari ketidakpastian pada jadwal proyek melalui besar buffer yang dihasilkan. Persamaan ini diharapkan dapat menghasilkan jadwal proyek dengan kinerja yang lebih baik dalam menghadapi beragam ketidakpastian daripada jadwal yang dihasilkan dengan metode pengukuran buffer terdahulu (Ma et al., 2014). Patut digarisbawahi bahwa ukuran buffer yang dikembangkan dengan metode UAM tidak selalu lebih besar dari ukuran buffer yang dikembangkan dengan metode terdahulu. Saat sebuah proyek dilaksanakan dengan ketidakpastian yang sedikit (dimisalkan saat koefisien EU dan RP lebih kecil dari 1), UAM dilaporkan menghasilkan buffer yang kecil. Hal ini berguna untuk mengembangkan metode yang kompetitif dan mengamankan kesempatan bisnis. Ketika sebuah proyek dilaksanakan dengan ketidakpastian yang signifikan, UAM dilaporkan menghasilkan buffer yang kurang menarik dalam proposal bisnis (Ma et al., 2014). Meskipun kurang menarik, jadwal yang dihasilkan memiliki ketahanan yang baik terhadap beragam ketidakpastian sehingga memperkecil resiko keterlambatan proyek dan dengan begitu dapat menghindari kerugian (Ma et al., 2014).

\section{Ketidakpastian}

Menurut Ma et al. (2014), terdapat lima ketidakpastian yang dapat mengganggu jadwal proyek konstruksi, antara lain:

1. Environmental Uncertainty (EU), yaitu ketidakpastian yang disebabkan oleh lingkungan eksternal proyek (Ma et al., 2014).

2. Activity Complexity (AC), yaitu kompleksitas dari sebuah aktivitas yang ditentukan oleh kompleksitas dari activity chain (Tukel et al., 2006).

3. Risk Preference (RP). Ketika diberikan sebuah situasi yang identik, masing-masing tim proyek dapat menghasilkan penilaian risiko yang berbeda-beda dikarenakan adanya perbedaan dalam menyikapi situasi, kemampuan manajerial, dan kapasitas dalam pengambilan risiko. Oleh sebab itu, dampak yang disebabkan oleh tim proyek dalam implementasi proyek termasuk dalam ketidakpastian proyek (Ma et al., 2014).

4. Activity Flexibility (AF). AF mengindikasikan fleksibilitas dari aktivitas tertentu. Penelitian sebelumnya menunjukkan bahwa semakin kecil AF maka semakin kecil kemungkinan aktivitas untuk tepat waktu (Yang et al. 2009) sehingga diperlukan buffer yang lebih besar.

5. Resource Tightness (RT). RT diperhitungkan untuk mewakili ketidakpastian yang berhubungan dengan ketersediaan resource dan mengukur aksesibilitas resource untuk aktivitas tertentu ketika terjadi permintaan resource secara bersamaan dengan aktivitas lain (Ma et al., 2014).

Ketidakpastian yang chain-specific dan mempunyai efek global ke seluruh durasi proyek adalah Environmental Uncertainty, Activity Complexity, dan Risk Preference. Sementara itu, ketidakpastian yang activity-specific dan mempunyai efek terhadap individu kegiatan adalah Activity Flexibility dan Resource Tightness (Ma et al., 2014).

\section{Environmental Uncertainty}

Menurut Ma et al. (2014), EU mengacu pada ketidakpastian yang diakibatkan oleh lingkungan eksternal proyek dari berbagai macam faktor. Pengelompokkan faktor dapat terbagi menjadi dua, yaitu:

1. Faktor yang berkaitan dengan proyek (project-specific) seperti risiko kontrak dan stabilitas pasokan suplai.

2. Faktor yang tidak berkaitan dengan proyek (non-project-specific) seperti kondisi cuaca dan kondisi makroekonomi.

Untuk menggambarkan lingkungan eksternal proyek yang dikerjakan, Political, Economic, Social, and Technological (PEST) framework dapat diaplikasikan untuk menganalisis dampak dari faktor lingkungan eksternal proyek. PEST Framework adalah metode yang sudah banyak digunakan untuk menganalisis dampak lingkungan 
dan efeknya terhadap organisasi (Yingfa dan Hong 2010). Menurut Ma et al. (2014), berdasarkan rating dari PEST, keseluruhan lingkungan eksternal proyek dapat dikatergorikan dalam tiga tipe, yaitu menguntungkan (favorable), normal, dan tidak menguntungkan (unfavorable). Masing-masing tipe ini ditentukan nilai EU yang dapat mengilustrasikan tingkat ketidakpastian pada proyek.

$$
\mathrm{EU}= \begin{cases}0.9 & \sum_{i=1} \mu_{i} \geq 3 \\ 1 & 1.5 \leq \sum_{i=1} \mu_{i} \leq 3 \\ 1.1 & \sum_{i=1} \mu_{i} \leq 1.5\end{cases}
$$

$\mu_{\mathrm{i}}(\mathrm{i}=1,2,3,4)$ dilambangkan sebagai evaluasi para ahli terhadap kondisi lingkungan mengenai political, economic, social, and technological. Dapat dilihat pada persamaan (1), rating PEST yang kecil mengindikasikan ketidakpastian yang besar dan ketidakpastian yang besar diasosiasikan dengan nilai EU juga semakin besar. Maka, nilai EU 0.9 diartikan sebagai ketidakpastian yang kecil, nilai EU 1 diartikan sebagai ketidakpastian yang normal, dan nilai EU 1.1 diartikan sebagai ketidakpastian yang besar. Koefisien EU yang didapat berdasarkan penelitian yang dilakukan Ma et al. (2014) pada 3 proyek konstruksi di China adalah 1. Koefisien EU 1 menandakan bahwa terdapat ketidakpastian yang normal pada proyek konstruksi di China.

\section{Relative Importance Index}

Kometa et al. (1994) dan Sambasivan dan Soon (2007) menggunakan metode RII untuk menentukan relative importance dari berbagai penyebab keterlambatan. RII akan dikalkukasikan pada setiap faktor atau pernyataan (i) berdasarkan jawaban responden dan dihitung menggunakan persamaan (6).

$$
R I I_{i}=\frac{n_{1}+2 n_{2}+3 n_{3}+4 n_{4}+5 n_{5}}{5\left(n_{1}+n_{2}+n_{3}+n_{4}+n_{5}\right)}
$$

Keterangan

RII $_{i} \quad=$ Relative Importance Index untuk tiap faktor $i$.

$n_{1}, n_{2}, n_{3}, n_{4}, n_{5}=$ Jumlah responden yang memberi skor "1" mewakili sangat tidak berpengaruh; "2" mewakili sedikit berpengaruh; “3” mewakili cukup berpengaruh; “4” mewakili banyak berpengaruh; “5” mewakili sangat berpengaruh.

\section{METODOLOGI PENELITIAN}

\section{Metode Pengumpulan Data}

Metode yang digunakan untuk pengumpulan data penelitian ini adalah dengan menyusun dan menyebarkan kuesioner ke beberapa proyek konstruksi di Jakarta. Jumlah kuesioner yang disebar adalah 70 lembar, dan yang memenuhi persayaratan adalah 53 lembar. Persyaratan yang dimaksud adalah ahli yang bekerja di bidang konstruksi seperti Project Manager, Site Manager, dan Site Engineer. Syarat lainnya adalah minimal berpendidikan S1 (Strata 1) dan telah bekerja di bidang konstruksi minimal selama 5 tahun pengalaman kerja. Sistem penilaian yang digunakan pada kuesioner ini adalah skala likert dengan nilai 1 merupakan nilai minimal (Tidak Setuju) sampai nilai 5 merupakan nilai maksimum (Sangat Setuju).

\section{Metode Analisis Data}

Metode analisis yang digunakan untuk menganalisa data menggunakan metode Relative Importance Index (RII) yang dibantu dengan program Microsoft Excel untuk mengolah data. Sebelum dilakukannya analisis data, perlu adanya studi literature dengan mencari dasar - dasar teori dan sumber data seperti journal, buku referensi untuk mendapatkan faktor eksternal yang berpengaruh dalam Environmental Uncertainty (EU).

\section{ANALISIS DAN PEMBAHASAN}

\section{Data Kuesioner yang Diperoleh dari Responden}

Hasil data dari penyebaran kuesioner dapat dilihat pada Tabel 1. 
Tabel 1. Data Hasil Kuesioner

\begin{tabular}{|c|c|c|c|c|c|c|}
\hline Nom & Butir Pernyataan & 1 & 2 & 3 & 4 & 5 \\
\hline 1 & $\begin{array}{l}\text { Risiko yang timbul akibat } \\
\text { gagal memenuhi kontrak yang telah } \\
\text { disepakati mempengaruhi pekerjaan } \\
\text { proyek sehingga mengganggu jadwal } \\
\text { konstruksi yang telah direncanakan }\end{array}$ & 0 & 1 & 9 & 22 & 21 \\
\hline 2 & $\begin{array}{llr}\text { Stabilitas } & \text { pasokan } & \text { suplai } \\
\text { yang dibutuhkan } & \text { proyek } \\
\text { mempengaruhi pekerjaan } & \text { proyek } \\
\text { sehingga mengganggu jadwal } & \text { jonstruksi yang telah direncanakan }\end{array}$ & 0 & 0 & 2 & 27 & 24 \\
\hline 3 & $\begin{array}{l}\text { Kondisi cuaca saat proyek } \\
\text { berlangsung mempengaruhi pekerjaan } \\
\text { proyek sehingga mengganggu jadwal } \\
\text { konstruksi yang telah direncanakan }\end{array}$ & 0 & 3 & 14 & 18 & 18 \\
\hline 4 & $\begin{array}{lrr}\text { Pertumbuhan } & \text { ekonomi } & \text { nasional } \\
\text { dan stabilitas } & \text { harga } & \text { pasar } \\
\text { mempengaruhi } & \text { pekerjaan } & \text { proyek } \\
\text { sehingga mengganggu } & \text { jadwal } \\
\text { konstruksi yang telah direncanakan }\end{array}$ & 0 & 10 & 15 & 20 & 8 \\
\hline
\end{tabular}

\section{Perhitungan Relative Importance Index (RII)}

Hasil perhitungan Relative Importance Index dapat dilihat pada Tabel 2.

Tabel 2. Hasil Perhitungan RII

\begin{tabular}{|c|c|c|c|c|c|c|c|c|}
\hline \multirow{2}{*}{ No } & \multirow{2}{*}{ Faktor } & \multicolumn{5}{|c|}{ Skor dari Responden } & \multirow{2}{*}{ RII } & \multirow{2}{*}{ Ranking } \\
\hline & & 1 & 2 & 3 & 4 & 5 & & \\
\hline 1 & Risiko Kontrak & 0 & 1 & 9 & 22 & 21 & 0.837736 & 2 \\
\hline 2 & $\begin{array}{c}\text { Stabilitas Pasokan } \\
\text { Suplai }\end{array}$ & 0 & 0 & 2 & 27 & 24 & 0.883019 & 1 \\
\hline 3 & Kondisi Cuaca & 0 & 3 & 14 & 18 & 18 & 0.792453 & 3 \\
\hline 4 & $\begin{array}{c}\text { Kondisi } \\
\text { Makroekonomi }\end{array}$ & 0 & 10 & 15 & 20 & 8 & 0.698113 & 4 \\
\hline
\end{tabular}

Peringkat RII dapat dilihat pada Tabel 3.

Tabel 3. Peringkat RII

\begin{tabular}{ccc}
\hline Ranking & Faktor & RII \\
\hline 1 & Stabilitas Pasokan Suplai & 0.883019 \\
\hline 2 & Risiko Kontrak & 0.837736 \\
\hline 3 & Kondisi Cuaca & 0.792453 \\
\hline 4 & Kondisi Makroekonomi & 0.698113 \\
\hline
\end{tabular}

\section{Analisis Variabel $\mu$}

Hasil perhitungan $\mu$ dapat dilihat pada Tabel 4. 
Tabel 4. Perhitungan $\mu$

\begin{tabular}{ccccc}
\hline Ranking & Faktor & RII & Skor Evaluasi $(\mu)$ & $\mu_{\mathrm{i}}(\mathrm{RII} * \mu)$ \\
\hline 1 & Stabilitas Pasokan Suplai & 0.883019 & 0.4 & 0.353208 \\
\hline 2 & Risiko Kontrak & 0.837736 & 0.3 & 0.251321 \\
\hline 3 & Kondisi Cuaca & 0.792453 & 0.2 & 0.158491 \\
\hline 4 & Kondisi Makroekonomi & 0.698113 & 0.1 & 0.069811 \\
\hline & & & $\sum_{i=1} \mu_{\mathrm{i}}=$ & 0.83283 \\
\cline { 3 - 5 } & & & &
\end{tabular}

\section{Besaran Koefisien Environmental Uncertainty (EU)}

Untuk mendapatkan koefisien Environmental Uncertainty dari $\Sigma_{\mathrm{i}}=1 \mu_{I}$ yang didapat dari perhitungan RII, digunakan model dari penelitian sebelumnya seperti pada persamaan (5).

Karena $\sum_{i}=1 \mu_{i}$ yang didapat adalah 0.83283, maka koefisien EU yang diperoleh dari proyek konstruksi di Jakarta adalah 1.1 ( $0.83283 \leq 1.5$ ). Koefisien 1.1 ini menandakan bahwa terdapat ketidakpastian yang besar pada proyek konstruksi di Jakarta. Ketidakpastian yang besar akan menghasilkan buffer yang besar. Karena buffer besar, jadwal yang dihasilkan menjadi kurang kompetitif. Tapi di lain sisi, Ma et al. (2014) menjelaskan bahwa meski buffer yang dihasilkan kurang menarik, jadwal yang dihasilkan memiliki ketahanan yang baik terhadap berbagai ketidakpastian. Ketahanan yang baik terhadap ketidakpastian pada akhirnya dapat mengurangi risiko keterlambatan pada proyek sehingga menghindari kerugian.

Dari hasil perhitungan Relative Importance Index (RII), stabilitas pasokan suplai adalah faktor Environmental Uncertainty (EU) yang paling berpengaruh dalam penjadwalan proyek. Stabilitas pasokan suplai diperlukan dalam penjadwalan berbasis Critical Chain Project Management (CCPM). Hal ini dikarenakan dasar dari penjadwalan CCPM yang berdasarkan resource sehingga membutuhkan resource secara terus menerus (continue). Kestabilan resource dalam penjadwalan CCPM ini sesuai dengan yang dikatakan Bie et al. (2012) dan Long dan Ohsato (2008), yaitu alur (workflow) yang lancar dibutuhkan dalam metode CCPM dikarenakan peran resource yang penting dalam critical chain dan dapat mengubah penjadwalan proyek (Bie et al., 2012; Long dan Ohsato, 2008).

\section{KESIMPULAN}

Adapun kesimpulan dari hasil analisis dalam penelitian ini yaitu:

1. Berdasarkan perhitungan yang telah dilakukan koefisien Environmental Uncertainty (EU) yang didapat berdasarkan perhitungan RII adalah 1.1. Koefisien ini menunjukkan bahwa terdapat ketidakpastian yang besar pada proyek di Jakarta.

2. Dari hasil perhitungan Relative Importance Index (RII), stabilitas pasokan suplai adalah faktor Environmental Uncertainty (EU) yang paling berpengaruh dalam penjadwalan proyek dengan nilai RII sebesar 0.883019, sedangkan kondisi makroekonomi menjadi faktor yang paling kurang berpengaruh dalam penjadwalan proyek dengan nilai RII sebesar 0.698113.

\section{DAFTAR PUSTAKA}

Bevilacqua, M., Ciarapica, F. E., dan Giacchetta, G. (2009). “Critical Chain and Risk Analysis Applied to HighRisk Industry Maintenance: A Case Study”. International Journal of Project Management, 27(4) 419-432.

Bie, L., Cui, N., dan Zhang, X. (2012). "Buffer Sizing Approach with Dependance Assumption between Activities in Critical Chain Scheduling”. International Journal of Production Research, 50(24), 7343-7356.

Cohen, I., Mandelbaum, A., dan Shtub, A. (2004). "Multi-Project Scheduling and Control: A Processbased Comparative Study of the Critical Chain Methodology and Some Alternatives”. Project Management Journal, 35(2), 39-50.

Goldratt, E. M. (1997). Critical Chain. New York: The North River Press.

Herroelen, W., dan Leus, R. (2001). “On the Merits and Pitfalls of Critical Chain Scheduling”. Journal of Operations Management, 19(5), 559-577.

Kometa, S. T., Olomolaiye, P. O., dan Harris, F. C. (1994). "Attributes of UK Construction Clients Influencing Project Consultants perfromance”. Construction Management and Economics, 12(5), 433-443.

Leach, L. P. (2005). Critical Chain Project Management. $2^{\text {nd }}$ ed. London: Artech House Inc. 
Long, L.D., dan Ohsato, A. (2008). "Fuzzy Critical Chain Method for Project Scheduling under Resource Constraints and Uncertainty”. International Journal of Project Management, 26 (6), 688-698.

Ma, G., Wang, A., Li, N., Gu, L., dan Ai, Q. (2014). "Improved Critical Chain Project Management Framework for Scheduling Construction Projects”. Journal of Construction Engineering and Management, 140(12): 04014055.

Patrick, S. F. (1999). Critical Chain Scheduling and Buffer Management, Getting Out from Between Parkinson's Rock and Murphy's Hard Place. PM Network, April.

Rabbani, M., et al. (2007). “A new Heuristic for Resource-Constrained Project Scheduling in Stochastic Networks Using Critical Chain Concept”. European Journal of Operational Research, 176 (2), 794-808.

Rand, G. K. (2000). “Critical chain: The Theory of Contsraints Applied to Project Management”. International Journal of Project Management, 18(3), 173-177.

Raz, T., Barnes, R., dan Dvir, D. (2003). “A Critical Look at Critical Chain Project Management”. Project Management Journal, 34(4), 24-32.

Sambasivan, M., dan Soon, Y. W. (2007). "Cause and Effects of Delays in Malaysian Construction Industry”. International Journal of Project Management, 25(5), 517-526.

Tukel, O. I., Rom, W. O., dan Eksioglu, S. D. (2006). “An Investigation of Buffer Sizing Techniques in Critical Chain Scheduling”. European Journal of Operational Research, 172(2), 401-416.

Yang, L., Li, S., dan Huang, X. (2009). “A Buffer Sizing Approach in Critical Chain Scheduling with Attributes Dependent”. Industrial Engineering and Management, 1, 11-14 (in Chinese).

Yingfa, S., dan Hong, Y. (2010). The risk study of e-governance based on PEST analysis model. Proc., Int. Conf. On E-Business and E-Government (ICEE), The Korean Institute of Electrical Engineers (KIEE), Seoul, Korea, 563-566. 